\title{
The Untranslatability in Translating English to Vietnamese and Vice Versa
}

\author{
Duy Nguyen ${ }^{1 *}$, Trang Nguyen Thi Thanh ${ }^{2}$ \\ ${ }^{I}$ Student at Nguyen Tat Thanh University \\ ${ }^{2}$ Teacher at Nguyen Tat Thanh University \\ "Corresponding author. Email: duynguyen2797@gmail.com
}

\begin{abstract}
In today's world where the trade of commercials is opened between many countries from all over the world has been on the continuous development from time to time, which leads to the vital play of communication between people and people from other countries causing so many problems in understanding to each other. So, the important roles of translation have been available more and more specifically and initially and the demands that requested to satisfy the need in a number of translators and interpreters in more increasingly and more well-trained. This demands the high intellectual levels in every translator in order to overcome a various number of language barrier problems as well as to solve as many problems appearing in all types of documents as possible. And one of the most difficult challenges, according to many translators in case of doing the translation between two contrary languages, especially to transfer some unable-to-translate words, means untranslatable words - so-called untranslatability. And this is the reason for our paper.
\end{abstract}

Keywords: cultural untranslatability, linguistic untranslatability, idioms

\section{INTRODUCTION}

Untranslatability, according to Catford (1965) [1], "translation fails - or untranslatability occurs - when it is impossible to build functionally relevant features of the situation into the contextual meaning of the TL text", are considered as one of the most difficult challenges that every translator has to face at least once, requiring of high level in professional ability of a translator, who is obligatory in order to attend to the inconclusive competition in this area - translation industry. In this paper, I would like to focus on the untranslatability in translation, how to deal with it, giving solutions, and contributing the new knowledge of the UN to the translation industry.

In order to satisfy that demand, there has been some research that mentioned this problem - the untranslatability - between English and another dialect (Catford, 1965 [1]; Cui, 2012 [2]; Mattar, 2014 [3]; Ping, 1999 [4] \& Wang, 2014 [5]). However, there is still no paper about the untranslatable words between English and Vietnamese, which could help to be supporting teaching as well as learning documents for both teachers and students majoring in Translation and Interpretation Department to deal with some relating problems, especially the unable-to-translate words. Moreover, due to the various number of proverbs and idioms in Vietnamese, which leads to the transforming between two languages - English and Vietnamese more impossible and more difficult due to no structural as well as grammatical equivalence as Catford (1965) [1] mentioned: "If the TL has no equivalent register, untranslatability may result." Besides, here are some hypotheses I want to make clear.

- How does untranslatability affect the quality of a translation?

- What are indispensable skills and knowledge for university students in Translation and Interpretation to deal with untranslatable words?

- How to overcome untranslatability?

To analyse this topic, I apply the qualitative method, which describes the property of a problem but not the numeric data, by using five documents as my secondary data that help me a lot in gathering non-number data from some theories in the last research. Moreover, since this topic of mine was written for the purpose of analysing how the UN affected translations and how to overcome, thematic data is the best choice, so I take samples by non-probability sampling method. Therefore, untranslatability is also one of the hardest 
parts, which causes the ambiguity for the beginner of translation.

\section{REVIEW OF LITERATURE}

As I mentioned before, this topic is based on some previous theories.

First, Catford (1965) [1] mentioned both kinds of untranslatability - linguistic and cultural - in analysing the pair of languages, English - Russian. moreover, by applying the qualitative method to analyse the conversion of two dialects as the problem of untranslatable words. he firstly defined cu as "what appears to be a quite different problem arises, however, when a situational feature, functionally relevant for the SL text, is completely absent from the culture of which the TL is a part" (catford,1965, pp. 99 [1]). Then, he defined LU as "Linguistic untranslatability occurs typically in cases where an ambiguity peculiar to the SL text is a functionally relevant feature" (Catford, 1965, pp. 99 [1]). As a result, Catford claimed that the aspect of culture takes the most important role in causing the untranslatable situation due to the different languages and cultures of each country.

Second, "An Approach to the Translation of Brand Names" (Wang, 2012 [6]) found out that untranslatable words could take place in translating names, especially brand names. Not only that, by using a qualitative method in analysing the relating papers which have the same topic and giving solutions in how to deal with the name translation. Moreover, he also stated that due to the increasing development of the global economy in many countries, people have to update their knowledge of a new language as well as keep track of new trends with the object of attracting domestic as wellbeing international customers.

The third paper, "An Analysis of Untranslatability between English and Chinese from Intercultural Perspective" (Wang, 2014 [5]), also had a new look at the impact of untranslatable words, however, on the translation between English and Chinese from the intercultural aspect. moreover, this paper was applied qualitative method by analysing how the hieroglyphics system in Chinese using could be rendered into English using Latin alphabetical system.

Fourth, "Overcoming Cultural Untranslatability: With Special Reference to Wikramasinghe's 'Gamperaliya' and its English Translation, 'Uprooted' by Lakshmi de Silva and Ranga Wikramasinghe" (Gunathilaka \& Ariyaratne, 2019 [8]) analysed the UN between English and Srilanka, in addition, with the purpose to make clear how CU could help to overcome the language barrier between these languages and the role of $\mathrm{CU}$ in translating. This paper also used the qualitative method in using other sources to solve the problems in solving this barrier.
In summary, these four papers are all focused on the impact of the UN on translating English to other languages but not to Vietnamese.

\section{AIMS \& THEORETICAL BACKGROUND OF RESEARCH}

\subsection{Definition of "untranslatability."}

According to Catford (1965) [1], "if the tl has no equivalent register, untranslatability may result. " Moreover, Furness and Hollis (2017) [9] stated that "untranslation is an installation that explores and celebrates the many languages spoken in Brixton. In lexicons worldwide, words exist that are untranslatable to the English language. Not any old words either". Overall, from some definitions of UN above, we can claim that an untranslatable word is simply a word, but it does not share the same meaning from the SL with the TL translation.

\subsection{What are the problems}

In order to solve this problem as well as to make clear the impact of the UN, I have three questions. First, how does untranslatability affect the quality of a translation? Second, what are the indispensable skills and knowledge for university students in Translation and Interpretation to deal with untranslatable words? Third, how to overcome the UN in translating?

\subsection{1. "How does the untranslatability affect the quality of a translation?"}

Catford (1965) [1] categorized the problems of 'untranslatability' into two types as follows

\subsubsection{Linguistic untranslatability (LU)}

To the linguistic type of untranslatability, there are two types itself listed as auxiliary verbs - so-called auxiliary - and verb "to be."

\subsubsection{1. "to be" in English and Vietnamese}

According to Random House Webster's Unabridged Dictionary (House, 2001 [10]), there have eleven situations of "to be" with different meanings. First, "to be" in the case of describing the state of remaining a life which means to exist or to live. For example, by the time the letter reached them, their sister had ceased to be (similar to 'died'). Second, "to be" is considered as the state of an action at a certain time, happening and occurring, and it expresses the performance of a verb which happens especially after previously being arranged or planned. "The birthday party was so fun" is an example of this kind of "to be." The third one is about an action of taking and holding possession of a specific location, place, or position. Fourth, it is considered as a description of a non-stop state of action as its original base and property as the main significance of to continue or to remain as before. Here is an example of this fourth "to be" in this applied-linguistic sentence: "The movie theatre is over there." The fifth 
one describes possession, belonging, and befalling. For example, "May good be with you." As the sixth definition of "be" description, it is considered as a copula, whose function is to connect words or phrases in a particular form of the verb "be" between a subject and compliment, to connect the subject with its predicate and to amplify subject. Here is an example for this, "Mr. John is the president." For the seventh use of "be," it is also used as a copula, however, to introduce or form the interrogative or imperative type of sentences. "Don't be lazy" is an example of this. To the eighth definition, with the user in case with the present participle of another verb to form the progressive tense with an example "She is waiting for him." In the ninth function, in this example, "He is seeing me today," "be" in this case is used with the present participle or infinitive of the principal verb with the purpose to indicate an exact future action. The tenth version of "be" is formed with the past participle of another verb to form the passive voice. For instance, "That car was fixed." Finally, as Random House Webster's Unabridged Dictionary (House, 2001 [10]), the eleventh use of "be," we can hardly seek this one since there is no one apply it into daily life nowadays due to its unpopular tense, however, it is used in literary constructions with some intransitive verbs to form the perfect tense and some antique documents. According to TẬP QUY TẮC CÚ PHÁP TIẾNG VIẸT (Thu, et al., n.d. [12]), there are only two forms of "to be" in Vietnamese can be understood as "thì" and "là" which have multiple meanings with different forms as well as in English. First, it is used in imperative sentences so as to ask someone or a group of people to do as a command from the speaker, for example, "Ai đồng ý thì giơ tay!". Second, it stands for a conjunction of cause-and-effect sentences to show result like this "Khi đun nước sôi ở 100 độ $\mathrm{C}$ thì nước sẽ chuyển từ thể lỏng thành thể khí". As a result, "Khi đun nước sôi ở 100 độ C" is the cause and the result will be "nước sẽ chuyển từ thể lỏng thành thể khí" with a conjunction-like "thì" in the middle of both cause and result. Third, it is used in compound sentences, a sentence of two or more coordinate independent clauses, often joined by a conjunction or conjunctions as the American Heritage Dictionary (Nelson, 2006 [11]) of the English Language defined. Normally, the first phase of a compound sentence is considered to be the main phrase that is used to inform the conditions, reasons, purposes, etc., for the existence of the post-phrase. For example, "Nếu bạn lười học thì bạn khó có thể thành công trong tương lai". As we can see, "thì" appears in the middle of the main phrase, and the sub phrase contains two functions. First is to express the supposed result "bạn khó có thể thành công trong tương lai" of the assuming cause "Nếu bạn lười học," and the second one is for the reason of linking both causing and resulting sides. According to tiengviet24h.com, "là" in Vietnamese has four ways to use. First, it could be understood as a copula or a linking verb which is used to connect two parts of a sentence. This one is quite similar to the sixth version of "to be" as Ransom House Webster's Unabridged Dictionary (House, 2001 [10]) included as I mentioned before and demonstrates that the two components of a phrase are semantically equivalent. However, it is not used to indicate the presence of an object in a specific location. Here are some examples:

"Tôi là người Việt Nam"

"Bây giờ là 8 giờ tối"

Second, "là" takes a role as a conjunction - defined as "used to indicate the presence of an object in a specific location" by English Oxford Dictionary (Stevenson (Ed.), 2010 [13]) - indicates an essential connection between the condition and the outcome with an example "Cứ hễ đến hè là tôi thấy vui". As the following example "Ba tôi dặn là khi ở nhà một mình không cho người la vào" as the third use of "là", the position of "là" is placed after a verb "dặn", which is similar to but not exactly phrasal verb, shows content or an idea that the main verb describes. Lastly, with the function as a particle used to emphasize a subjective assertion of an utterance, we could recognize that it "can be combined with several words that express more intensity to strongly assert something".

\subsection{The auxiliary verb in English and Vietnamese}

The next one is another problem for the UN in translating from English and Vietnamese and vice versa - the auxiliary verb. In English, there are two kinds of auxiliary verbs, which is the primary and the modals. Firstly, the primary auxiliary verb contains three forms itself, the first one is "be" - "am", "is", "our", "was", "were", "being", "been" and "will be". Next is "have" with "have", "has", "had", "having" and "will have". The Final is "does", "do", "did" and "will do". We use "do" as a kind of primary form of the auxiliary verb for a reason as a function of present simple tense and simple past tense in both interrogative and negative forms mostly but rarely in positive. Here is an example for this version of the primary auxiliary verb

$$
\begin{gathered}
\text { "Do you have a pen?" } \\
\text { - "Yes, I do" - "No, I do not." }
\end{gathered}
$$

The "have" kind of primary auxiliary verb is used in order to form the perfect tenses. In different situations, there will be separated forms of "have" that take alternative shapes. For instance, in case we are thinking about an action that had happened before a period of time in the past with no clear time and space, it is past perfect tense whose structure contains "had" with a verb in past-participle form; but in case we mention to a process that has happened before a time at present, and after a specific time in the past, we use "have" in the plural form and "has" in singular form and is followed by a past participle form of word of action. And here is the final important type of primary auxiliary verb. As some functions own themselves, "be" can only be used in order to perform continuous tenses, which expresses 
an action in a non-stop and remaining way in two different directions of expressing ideas. Firstly, it performs an action that remains as before and keeps itself in one straightway that could be explained briefly as to continue. For instance, "I am doing homework at the moment". This shows an action "doing" at a specific time, "at the moment," and at the time a speaker is performing an action of saying. Secondly, it is usually in the written method and similar to future simple tense; however, there is a deliberate performing of action while future simple does not include. Here are two examples showing the big differences between "be verbing" structure - considered as near future - and "will verb" structure - as a future simple composition,

$$
\text { "It will rain", }
$$

For the first example, the action "rain" expresses a chance with $50 \%$ of rain; moreover, it is considered as an utterance that is made as not a full sentence but as a blurting out at that time. However, at the sentence marked "(2)", there are two different situations for this and firstly is the liability of "rain" which is at a very high rate that we can ensure that it will definitely rain and there is no way to object it; secondly, it describes the uninterrupted flow of rain that is taking place during the specific time a speaker is expressing in their speech.

Next, according to Merriam Webster's Dictionary (Websters, 1987 [14]). Modern. the modal auxiliary is "characteristically used with a verb of predication and expresses a modal modification and that in English differs formally from other verbs in lacking "-s" and "ing" forms." Modal auxiliary verbs - so-called modals are only used before a bare-infinitive form of verb so as to change a little meaning to the source one. For example, if I say "I read books," it is simply an action "read" performing on "books" as a noun; but if I say "I can read Japanese books," which means I have an ability to recognize a language - Japanese. These two examples are different in both structural and linguistic functions. Here are two examples of translating auxiliary verbs from English to Vietnamese as the following table

\begin{tabular}{|c|c|c|}
\hline No & English & \multicolumn{1}{|c|}{ Vietnamese } \\
\hline 1 & $\begin{array}{l}\text { "Would you like to } \\
\text { have a cup of coffee?" }\end{array}$ & $\begin{array}{l}\text { "Xin mời bạn uống } \\
\text { cà-phê" }\end{array}$ \\
\hline 2 & $\begin{array}{l}\text { "I have visited this } \\
\text { museum ten times" }\end{array}$ & $\begin{array}{l}\text { "Tôi đến tham quan bàn bảo tàng này } \\
\text { được mười lần rồi” }\end{array}$ \\
\hline
\end{tabular}

Table 1. translating auxiliary verb from English to

Vietnamese

In the first pair, we could see that "would" cannot be translated into Vietnamese due to its vital role in a grammatical function of a sentence but not deciding the meaningful function itself. This one must be based on situational meaning. To the second one, it is a past participle form of the verb following after a modal verb - "have" - to express an action or a situation that happened in the past with no certain time and may continue to the present. From those two instances, it is impossible to render auxiliary verbs from English to Vietnamese without changing their meaning. So this one is untranslatability.

Second, according to TẬP QUY TẮC CÚ PHÁP TIÊNG VIÊT (Thu, et al., n.d. [12]), there are only two forms of "to be" in Vietnamese can be understood as "thì" and "là" which have multiple meanings with different forms as well as in English. First, "thi" is used in imperative sentences to ask someone or a group of people to do as a command from the speaker, for example, "Ai đồng ý thì giơ tay!". Second, it stands for a conjunction of cause-and-effect sentences to show result like this "Khi đun nước sôi ở 100 độ $\mathrm{C}$ thì nước sẽ chuyển từ thể lỏng thành thể khí". As a result, "Khi đun nước sôi ở 100 độ C" is the cause and the result will be "nước sẽ chuyển từ thể lỏng thành thể khí" with a conjunction-like "thì" in the middle of both cause and result. Third, it is used in compound sentences, a sentence of two or more coordinate independent clauses, often joined by a conjunction or conjunctions as the American Heritage Dictionary (Nelson, 2006 [11]) of the English Language defined. Normally, the first phase of a compound sentence is considered to be the main phrase that is used to inform the conditions, reasons, purposes, etc., for the existence of the post-phrase. For example, "Nếu bạn lười học thì bạn khó có thể thành công trong tương lai". As we can see, "thì" appears in the middle of the main phrase, and the sub phrase contains two functions. First is to express the supposed result "bạn khó co thể thành công trong tương lai" of the assuming cause "Nếu bạn lười học," and the second one is for the reason of linking both causing and result in sides. According to tiengviet24h.com, "là" in Vietnamese has four ways to use. First, it could be understood as a copula or a linking verb which is used to connect two parts of a sentence. This one is quite similar to the sixth version of "to be" as Ransom House Webster's Unabridged Dictionary (House, 2001 [10]) included as I mentioned before and demonstrates that the two components of a phrase are semantically equivalent. However, it is not used to indicate the presence of an object in a specific location. Here are some examples:

\section{"Tôi là người Việt Nam" \\ "Bây giờ là 8 giờ tối"}

Second, "là" takes a role as a conjunction - defined as "used to indicate the presence of an object in a specific location" by Oxford Dictionary (Stevenson (Ed.), 2010 [13]) - indicates an essential connection between the condition and the outcome with an example "Cứ hễ đến hè là tôi thấy vui". As the following example "Ba tôi dặn là khi ở nhà một mình không cho người lạ vào" as 
the third use of "là," the position of "là" is placed after a verb "dặn," which is similar to but not exactly phrasal verb, shows content or an idea that the main verb describes. Lastly, with the function as a particle used in order to emphasize a subjective assertion of an utterance, we could recognize that it "can be combined with a number of words that express more intensity to strongly assert something."

\subsubsection{Cultural untranslatability (CU)}

The second type of untranslatability is about the cultural one. It is defined that cultural untranslatability alludes to the difficulties in translation that start from the gap between the source dialect culture and the target dialect culture. This happens uncommonly in translating cultural perspectives of a dialect, such as names of individuals, nourishments, and theoretical, cultural concepts and terms. It makes the rendering of the source content more troublesome within the target one. Here are some specific types of untranslatability in culture. Firstly, folklore is, according to the American Heritage Dictionary of the English Language (Nelson, 2006 [11]), "traditional beliefs, myths, tales, and practices of a people, transmitted orally." Here is an example of folklore:

\section{"Tết Công-gô"}

What firstly bears in your mind when you want to translate it into English? Is it "Cong-go Tet"? According to Vietnamese meaning, when someone mentions this phrase which means it will never happen. In some very specific situations, like when a child's parents promise to buy him/her a favorite toy just for a reason to stop the baby's crying, they say, "We promise to buy you that toy on Cong-go Tet holiday." However, there is no parallel version of "Tết Công-gô" in English due to the fact that this one comes from the culture of Southeast Asian countries. So, the best way is to render it into a similar meaning to transfer easily for both readers and translators. In another example of folklore from English:

\section{"Flat wine can cause drunkenness with large consumption \\ Great speakers can create boredom with lengthy orations."}

At the first look, we can understand a little about this folklore's overall meaning through using literal translation techniques. Could it be translated into

\section{"Rượu ngon có thể gây say xỉn khi uống nhiều \\ Người nói hay có thể gây nhàm chán khi nói nhiều"?}

Well, there is a false in the role of building construction of Vietnamese folklore system especially the finding rhymes technique - which is considered as one of the most specific characteristics appearing in most of the folklores, expressions in the sin-eight-word distich meter - which means a style of poetry with many six- words-on-the-front and eight-words-below structures so-called "lục bát" in Vietnamese - combining to form meaningful poetry that is used for the purpose of transmitting many messages for the next generations. In this case, we need to keep the source of this folklore in Vietnamese instead of translating it literally.

\section{“Rượu nhạt uống lắm cũng say \\ Người khôn nói lắm dẫu hay cũng nhàm"}

The second type of cultural untranslatability I want to mention is the proverb, according to Cambridge Dictionary (Peters, 2013 [15]), "a short sentence, etc., usually known by many people, stating something commonly experienced or giving advice," as some instances below

\section{"When in Rome, do as the Romans do"}

This proverb means to advise people to be used to and sociable with a place or a community where we are living without a demand. So, in Vietnam, we have a very simple way to express this.

"Nhập gia, tùy tục"

In the literal sense, it means when we join in a family, we must know that family's rules to behave ourselves in order not to be stuck in trouble. But in figurative one, it simply means to integrate. Or with another example,

\section{"Vỏ quít dày có móng tay nhọn"}

To this one, it describes the action of using nails to detach a fruit's skin to have it. Depending on how sharper your nails are, it is easier to peel. That is the literal meaning. So how about the figurative? It means that no one in the world is the best, so never be presumptuous. In this case, we should keep the original translation of English as

\section{"Diamond cuts diamond."}

Thirdly, relating to untranslatability, we have expressions, which is the "act of saying what you think or showing how you feel using words or actions" according to Online Cambridge Dictionary, as some examples below.

\section{"Best thing since sliced bread"}

This reminds us of the wonderful smell of bread after being cut into each slice. However, as the literal meaning, it means to describe a flat of bread that has just been cut is always new, and this term originates from the $20^{\text {th }}$ century when sliced-loaf bread is the best seller and the most consumption. In figurative one, it relates to the good characteristics of a person or good quality of a product as a sentence

SL

TL 


\begin{tabular}{l|l|}
$\begin{array}{l}\text { "This phone of our } \\
\text { company is the best thing } \\
\text { since sliced bread" }\end{array}$ & $\begin{array}{l}\text { "Sản phẩm điện thoại của } \\
\text { cống tyúng tôi là hàng } \\
\text { rất tôt" }\end{array}$
\end{tabular}

Table 2 Translating expression from English to

Vietnamese

Or in another one from Vietnamese to English we have

\begin{tabular}{|l|l|}
\hline \multicolumn{1}{|c|}{ SL } & \multicolumn{1}{|c|}{ TL } \\
\hline $\begin{array}{l}\text { "Thua keo này, bày } \\
\text { keo khác" }\end{array}$ & $\begin{array}{l}\text { "When one door shuts, } \\
\text { another opens." }\end{array}$ \\
\hline
\end{tabular}

Table 3 Translating expression from Vietnamese to English

This sentence means to encourage that there will be another chance, do not be low-spirited after every loss.

In a word, folklores, proverbs and expressions are all connecting to one of the most specific points of culture in every country, so they are categorized as untranslatable words - so-called untranslatability which means they cannot be translated literally by applying some other kinds of translation, but the best way is to learn by heart and using helping tools such as dictionaries in both languages. Those are all about the untranslatability in the cultural aspect.

3.2.2. Indispensable skills and knowledge for university students in Translation and Interpretation to deal with untranslatable words.

\subsubsection{For normal translation document}

There are five ways in total to improve translation skills. The first is to read. Reading is one of the most important ways to ensure that our translation is up-todate, contextual, and meaningful is to read as many foreign languages as possible. The dictionary is the translator's bible and best friend. Carrying a book as often as possible and reading it in spare time to keep increasing idiolect. Moreover, read as many local newspapers, magazines, books, and publications as possible to understand trends, events, and cultural differences used in the language and research field. Finally, take the time to read as many articles translated by colleagues and predecessors as possible to learn about trading tips and tricks. Secondly, having a lot of conversations with native speakers of the problem language. There is no better way to learn a language than to speak it all the time while talking to the language experts and the people who were born with it. It's also a great way to understand the nuances of your target language, such as colloquial and slang words. Thirdly, Translators usually devote themselves to specialization, a specific field of study, in order to establish their profession and reputation. This is wise because it can enhance your credentials for clients who are looking for freelancers or professionals to translate materials in some particular fields. What you can do to further refine your resume is to obtain a degree or certification in such a field, which will enable you to demonstrate your authority on the subject. Fourthly, in case you are not familiar with the translation from English to another language, try translating in the opposite way. This will not only increase your knowledge of the relationship between the two languages but will also unlock the hitherto unknown ability to make bi-directional translations between language pairs. This broadens the range of projects you can use. Finally, it is very important for translators to become accustomed to CAT (computer-assisted translation) tools. The computer programs that can improve translation speed and quality of a translation. It also helps maintain overall consistency, avoid abbreviated lines and word instances. Repetitive phrases and word sets are provided with standardized translations. In case of working on the same project by multiple translators, the tool will allow us to work with all standard vocabulary sets. Widely available CAT tools include Linguee, SDL Trados, Fluency Now, MemoQ, and more. Besides, there is a big factor that has an effect on choosing which software to use is about comfortable price levels, client requirements, and the file format you are working on will influence your final choice. It is important to look at the means by which translators can support and improve their work without being wary of using translation software.

\subsubsection{For 'untranslatability'}

The crudest of these is an adjustment - to broadly interpret "a potato" as "a rice grain" on the premise that they are the two languages' primary staple nourishment. Another predominant strategy is borrowing, which apportions with translation altogether and receives the remote word as modern vocabulary. Compensation is another way to precise the untranslatability of dialect transformation. Numerous dialects of the world have distinctive words for the same thing. One way to bargain with untranslatability is calque. Firstly, calque endeavors to parse, or isolate, and express into its components. Secondly, it sets incites or something else made clear that the translation is of questionable creation. The trust is that the totality of these stringed words passes on the remote expression's outsider concept. Calquing regularly makes no sense, but it can be the translation of choice since it is an endeavor to be exacting. Rewording is a successful way of communicating that which isn't translatable in another dialect. It replaces a word or state in one dialect with an unequal word or expressed within the translation. The equivalency comes when the meaning is closely the same. With this technique, there's not as it was the endeavour to associate a lexical crevice but to bridge a social hole and discover human commonality in different dialects. The "untranslatable" meaning remains, 
which cannot be found in the target language, prompting some linguists to declare "impossible" in a theoretical sense. It will, however, serve to remind the translators that the UN has more to do with linguistic characteristics, not with the particular traveller's talents or the limitations of the skill. The difficulty is that the universe is divided in different ways into distinct cultures, and consequently, their languages have ideas and phrases to explain the various notions and cultural traits. In certain circumstances, the problem of UN is indeed irrelevant, and the translator is eventually reduced to leaving the term in the original language and providing an explanatory footnote or paraphrase after scanning all dictionaries on the shelf. But difficulty should not be confused with untranslatability. There are various ways in which words and words can be translated that do not travel well from one language to another, and "untranslatability" is frequently a misnomer, since a precise or complete translation is not required, and everything that is required in a particular context is an approximate equivalent. Dealing with "untranslatable" utterances, it is necessary to remember that the same notion might be expressed in several ways. Sometimes, by discovering the corresponding register or language level, an apparent 'untranslatable' case may be resolved. Since meaning is largely contextual, the context in which a word appears may make the term at first look "untranslatable." But there is often a problem of "not seeing the forest for the trees." In every country, there are always slangs and expressions which base on every different culture. For instance, in Vietnam, when we want to give our praises to the man who is very strong, and he can deal with many problems by using the power of his body, we say "chú ây /anh ấy/thằng này khỏe như trâu vậy!". So, in pair of two languages, Vietnamese and English, does it make sense if we translate this phrase using the word-by-word technique from Vietnamese to English as "He is as strong as a buffalo"? We can, and the readers could understand the main idea. But it is illogical due to the fact that this pair of languages contains different cultures, so there is no for "as strong as a buffalo." It must be "as strong as a horse" instead. Similarly, if one considers the social context in which they are employed, one may frequently find analogs for supposedly "untranslatable" contemporary coinages or neologisms. One clarification stated that the tradition inferred from the Pagans thought that trees were the places where pixies, spirits, dryads, and numerous other supernatural animals stay. On these occasions, individuals might thump or touch wood to ask great luckiness or to occupy spirits with an evil force. However, the meaning of "touch wood" cannot be translated into Vietnamese due to the fact that there has no way to transfer from the ST - English - to the TT Vietnamese - as the definition according to English Vietnamese Dictionary (Jones, 1956 [16]). Claimed that this is the normal way when you use your hand to touch a thing made of wood with the hope of being superstitious or humorous so order to keep out bad luck. For instance, in English, we have:

I've been driving for 25 years and never had an accident - touch wood!

While in Vietnamese we have:

Tôi đã lái xe 25 năm nay và chưa hề gặp tại nạn - phỉ thui!

To make the topic more clearly, there will be some examples such as "đìu hiu", "đắng lòng" và "đa đoan," etc. For "đìu hiu", according to LacViet Dictionary, it is "buồn bã, vắng vẻ" which describes the emptiness of the landscape but not for human's emotion. So, this is just the equivalent description but not a definition from Vietnamese - the ST - into English - the TT.

The same as this one, we have "đắng lòng." This is a word, which is not available in the Vietnamese dictionary, started from folklore over hundred years ago. However, there have a lot of definitions such as "bitterness," but in fact, "đắng lòng" has a funny meaning used to express many different emotional responses without containing negative meaning.

"Đa đoan" is the same as "đắng lòng" due to no information in the Vietnamese dictionary. But its meaning is about a person who always gets troubles in many cases, especially in bonds of love. However, it doesn't mean troublemaker or amative.

\subsubsection{How to overcome the 'untranslatability' in translation}

\subsubsection{For normal translation document}

So, the question which we have to make sure of is how to overcome, I mean to deal with the problems of untranslatable words, considered to be the nightmare of every translator in pair of two languages - Vietnamese and English - but still keep the natural meaning of each one. There are five ways in total to improve translation skills. The first is to read. Reading is one of the most important ways to ensure that our translation is up-todate, contextual, and meaningful is to read as many foreign languages as possible. The dictionary is the translator's bible and best friend. Carrying a book as often as possible and reading it in spare time to keep increasing idiolect. Moreover, read as many local newspapers, magazines, books, and publications as possible to understand trends, events, and cultural differences used in the language and research field. Finally, take the time to read as many articles translated by colleagues and predecessors as possible to learn about trading tips and tricks. Secondly, having a lot of conversations with native speakers of the problem language. There is no better way to learn a language than to speak it all the time while talking to the language experts and the people who were born with it. It's also a great way to understand the nuances of your target language, such as colloquial and slang words. Thirdly, Translators usually devote themselves to specialization, 
a specific field of study, in order to establish their profession and reputation. This is wise because it can enhance your credentials for clients who are looking for freelancers or professionals to translate materials in some particular fields. What you can do to further refine your resume is to obtain a degree or certification in such a field, which will enable you to demonstrate your authority on the subject. Fourthly, in case you are not familiar with the translation from English to another language, try translating in the opposite way. This will not only increase your knowledge of the relationship between the two languages but will also unlock the hitherto unknown ability to make bi-directional translations between language pairs. This broadens the range of projects you can use. Finally, it is very important for translators to become accustomed to CAT (computer-assisted translation) tools. The computer programs that can improve translation speed and quality of a translation. It also helps maintain overall consistency, avoid abbreviated lines and word instances. Repetitive phrases and word sets are provided with standardized translations. In case of working on the same project by multiple translators, the tool will allow us to work with all standard vocabulary sets. Widely available CAT tools include Linguee, SDL Trados, Fluency Now, MemoQ, and more. Besides, there is a big factor that has an effect on choosing which software to use is about comfortable price levels, client requirements, and the file format you are working on will influence your final choice. It is important to look at the means by which translators can support and improve their work without being wary of using translation software

\subsubsection{For 'untranslatability'}

According to 'A Textbook of Translation' (Newmark, 1988 [17]), there are 20 strategies in total to overcome the barrier of language translation - untranslatability as follows.

Firstly, we need to transfer the SL words into TL for some words like a name, proper nouns, or titles. For instance, with a sentence in Vietnamese like

"Xin chào mừng quý khách đến với Núi Bà Đen”

Is it alright for

"Welcome to Black Lady Mountain"?

Well, due to the fact that "Bà Đen" is the property name of that mountain, so there is no way to render excepts keeping it in the TL translation. It must be

\section{"Welcome to Ba Den Mountain"}

In another example of this, "Truyện Kiều" is the title of the story about a life of a character named Thúy Kiều from a very long time ago. It cannot be translated into "Kiều Story" even though "Truyện" in Vietnamese is "story" in English. According to Peter Newmark, he noticed that in the transference strategy, translators must not render the names, titles, and proper nouns appearing in the text, but they must keep it in the TL.

Secondly, as Peter Newmark mentioned, 'transcription' - which is considered as a word that borrows from another language and keeps its original form, next, "Áo dài," one of the most beautiful cultural specificities of Vietnam, is an example of a translation from Vietnamese to English. According to Wikipedia, "Áo dài" is the Vietnamese national and traditional clothing which is suitable for both men and women on many formal occasions, for example, in a meeting, in a hotel, or a restaurant, etc. Due to its traditional cultural characteristic itself, there is no way to transfer it into English excepts for keeping the source "Ao Dai", moreover, it is also a specific name and a traditional suit, so it should be capitalized in writing. Besides, "bánh mì" in Vietnamese is also kept as the source in case of translating into English. According to The American Heritage Dictionary (Nelson, 2006 [11]), "banh mi" is defined as Vietnamese sandwiches made with a variety of meats, pickles, or fresh vegetables, usually, sriracha or other spicy condiments, which are traditionally served on baguettes made from both wheat and rice flour. Because "banh mi" is similar to "Ao Dai," besides, this has been a traditional food in Vietnam for a very long time, and when people mention "banh mi," they will probably think about Vietnam.

Thirdly, 'transliteration' is also the term alluding to some words that could not be rendered exactly into another dialect, but it helps you to pronounce that word correctly. It sounds like the international phonetic alphabet in English, which could help English learners to be easier for their English pronunciation. For instance, "tuýp" in Vietnamese has an exactly similar sound to "tube" in English as in the following sentences:

\begin{tabular}{|c|c|}
\hline $\begin{array}{l}\text { - "Excuse me, I want } \\
\text { to buy a tube of } \\
\text { toothpaste" }\end{array}$ & $\begin{array}{l}\text { - “Xin lỗi, bán cho } \\
\text { tôi một tuýp kem } \\
\text { đánh răng" }\end{array}$ \\
\hline
\end{tabular}

Table 4 Lexical transliteration from English to Vietnamese

As we can see, "tube" (/tju:b/) is directly transferred into "tuýp" from English to Vietnamese. Since no word in Vietnamese can be replaced for "tube" in English, so the easiest way is to pronounce by the TL styles and word rules. Or in another instance, we have

\begin{tabular}{|l|l|}
\hline $\begin{array}{l}\text { - I can play } \\
\text { guitar" }\end{array}$ & $-\begin{array}{l}\text { "Tôi biết chơi đàn ghi- } \\
\text { ta" }\end{array}$ \\
\hline
\end{tabular}

Table 5 Lexical transliteration from English to Vietnamese

In this case, "guitar" /gi'ta:/, one of many well-known musical instruments, is transferred into "ghi-ta" as the most similar sound as its pronunciation. Moreover, there 
is no type of musical instrument in Vietnam that is lookliked as guitar, so there is the only way to express this word that is to translate it into spell-as-it-sound form.

Fourthly, with the term 'transposition' that Peter Newmark mentioned in A textbook of translation (1986), it means to change a small unit of a grammatical function as a word in a sentence by different structure with different positions of that word. Here are two examples for 'transposition.'

\begin{tabular}{|l|l|}
\hline $\begin{array}{l}\text { A: "How are you today?" } \\
\text { B: "I'm fine. Thanks" }\end{array}$ & $\begin{array}{l}\text { A: "Hôm nay bạn khỏe } \\
\text { không?" } \\
\text { B: "Tôi khỏe, cảm ơn" }\end{array}$ \\
\hline $\begin{array}{l}\text { - "Before I had } \\
\text { breakfast, I had had a } \\
\text { walk" }\end{array}$ & - "Trước khi ăn sáng, \\
tôi đã đi bộ"
\end{tabular}

Table 6 Phrasal transposition from English to Vietnamese

In the first example from English to Vietnamese, "are" in this case plays a grammatical function in an English sentence; however, there is no "are" in the Vietnamese version. So, there is the only way to solve this is to skip the functional grammatical word in Vietnamese. In the second one, "had" also plays a grammatical function in the Past-participle form of verbs describing an action that had happened before a period of time in the past and may lengthen to the present.

Fifthly, 'transcreation,' one of the most interesting activities that perform and use translators' creation into rendering. There are so many cases in real life, like translating films' names, poems, etc. The following two examples of 'transcreation' as following

\begin{tabular}{|l|l|}
\hline - “Despicable Me” & $\begin{array}{l}\text { - “Kẻ Cắp Mặt } \\
\text { Trăng” }\end{array}$ \\
\hline - "Bố Già" & $-\quad$ "Dad, I'm Sorry" \\
\hline
\end{tabular}

Table 7 Phrasal transcreation between English and Vietnamese

In this case, translators have no other choice but to follow the content of the movie then create a new name based on it.

Sixthly, 'one-to-one translation' is the most popular technique that many people use for a fast translation. For example,

\begin{tabular}{|l|l|}
\hline - “a house" & - “căn nhà" \\
\hline
\end{tabular}

Table 8 Lexical one-to-one translation from English to Vietnamese
In this case, "a" - an article - plays an important role in fulfilling the meaning of a noun as well as a grammatical function - singular or plural form - in a sentence; moreover, it is absolute that there is no article in Vietnamese. Then, the best way to render it is to skip it.

In the seventh strategy, 'through translation' - socalled literal translation - means to translate textually, and it should be used in already recognized terms. This one is similar to calque and loan word. However, it is different from word-by-word translation. Here is an example for 'through translation' as below

\begin{tabular}{l|l} 
Acquired Immuno- & $\begin{array}{l}\text { Hội chứng suy } \\
\text { giảm miễn dịch } \\
\text { mắc phải }\end{array}$
\end{tabular}

Table 9 Phrasal literal translation from English to Vietnamese

Usually, we apply this strategy to translate names of organizations, some common collocations, etc.

In the eighth strategy, Peter Newmark referred to some lexical synonymy, which is considered as one of the most difficult types of word translation due to its variety of a word in many different cultures. For instance, "già" in Vietnamese means the old man or a person who is more than 65 years old; however, how about "già làng"? Is it an old man in a village? There are fifty percent right and wrong. First, "già làng" expresses a man who are staying in that village for a very long time until now; second, that word is considered as the leader of that village. In another example, "đen" in Vietnamese shows a state of color - it means "black. But what does "đen đủi" mean? Does its meaning have a little similarity as "black"? Absolutely no, "đen đủi" is an adjective expressing a stroke of bad luck or the unlucky thing as an example below.

\begin{tabular}{l|l|}
\hline $\begin{array}{l}\text { - "Hôm nay quả thật } \\
\text { là một ngày đen } \\
\text { đủi!! }\end{array}$ & - "What a bad day \\
& today!" \\
\hline
\end{tabular}

Table 10 Lexical synonymy translation from Vietnamese to English

With the 'componential analysis' in the ninth strategy, Peter Newmark wants to express the various meanings of a word in many different situations, which may replace the main idea of the content. Briefly, it means a word for many meanings similarly. These examples will explain the overcoming of untranslatability

\begin{tabular}{|c|l|l|}
\hline \multirow{2}{*}{$\begin{array}{c}\text { "ăn” } \\
\text { (eat) }\end{array}$} & - Ăn sáng & $\begin{array}{l}\text { - Have breakfast } \\
- \text { Eat breakfast }\end{array}$ \\
\cline { 2 - 3 } & - Ăn ảnh & - Be photogenic \\
\hline
\end{tabular}




\begin{tabular}{|c|c|c|}
\hline \multirow{2}{*}{$\begin{array}{c}\text { Finish } \\
\text { (hoàn } \\
\text { thành) }\end{array}$} & $\begin{array}{l}\text { - I finished } \\
\text { my } \\
\text { homework }\end{array}$ & $\begin{array}{l}\text { - Tôi đã hoàn thành } \\
\text { bài tập về nhà }\end{array}$ \\
\cline { 2 - 3 } & $\begin{array}{l}\text { - "Finish } \\
\text { him!" }\end{array}$ & $\begin{array}{c}\text { - "Hạ gục anh ta } \\
\text { đi!" }\end{array}$ \\
\hline
\end{tabular}

Table 11 Translating componential analysis between English and Vietnamese

The first verb, "ăn" in Vietnamese, shows an action of putting food into our mouth and that food transforms into energy for our body, has two specific uses as I mentioned above as examples as we know that "ăn sáng" means to eat food in the morning. However, is "ăn ảnh" the same as "to eat" something? Unfortunately, "ăn ảnh" is the other different way to give a compliment about a person who is beautiful in the picture by their good performance. So, it is impossible to translate "ăn ảnh" by using word-to-word technique due to lacking meaningful content in TT. To make clear of this strategy, "finish" will be the next example for this. According to Longman Dictionary of Contemporary English, I have two translated versions above from the definition of "finish," which is "to complete the last part of something that you are doing," according to Longman Dictionary of Contemporary English, I have two translated versions above. First, it means to go to the end of the process of homework; however, the second sentence happens during a battle between two kickboxers with the moral support from the audience like: "Finish him!". In this case, "finish" does not keep the original meaning, which is to complete a work, anymore. Its meaning sounds similar to "beat" in English with "đánh bại" and "hạ gục" in Vietnamese.

Tenth, this strategy depends on how various points of view there are which takes place mostly in translating the same content but the results are completely different to each other even in one language to another language and vice versa, is 'modulation.' In order to prove that this technique can help translator overcome some problems occurring during translation, especially untranslatability - so-called untranslatable words, here are a few examples

\begin{tabular}{|c|c|}
\hline - "police" / “cop" & - “công an" / "cớm” \\
\hline - "bán muối” & - "to die" \\
\hline
\end{tabular}

Table 12 Translating modulation between English and Vietnamese

In the first example, "police," or "cop," is translated into "công an" in Vietnamese in a normal way. But, "cớm," is used as a touch of sarcasm and contemptuous word that Vietnamese people call for "công an" or "cảnh sát," is the untranslatable word because there is no parallel word in English has exact meaning as "cớm" in
Vietnamese. In the second example above, this is a traditional slang alluding the death. In order to have a fully understandable way of this, I will give you a small conversation as the situation below:

\begin{tabular}{|c|c|}
\hline ST & $\mathrm{TT}$ \\
\hline $\begin{array}{l}\text { A là bà con xa của } \mathrm{B} \text {. } \\
\text { Một hôm } \mathrm{A} \text { gọi hỏi } \\
\text { thăm sức khỏe } \mathrm{B}\end{array}$ & $\begin{array}{l}\text { A is the distant relative to } \\
\mathrm{B} \text {. One day, A called B to } \\
\text { inquire after their health }\end{array}$ \\
\hline $\begin{array}{l}\text { A hỏi B: "Ông C sao } \\
\text { rồi?" }\end{array}$ & $\begin{array}{l}\text { A asked B: "How is } \mathrm{Mr} \text {. } \\
\text { C?" }\end{array}$ \\
\hline & ( $\mathrm{C}$ is the husband of $\mathrm{B}$ ) \\
\hline (C là chồng của $\mathrm{B}$ ) & "He died!" - said B \\
\hline $\begin{array}{l}\text { B đáp: "Ổng đi bán } \\
\text { muối rồi!" }\end{array}$ & \\
\hline
\end{tabular}

Table 13 Translating traditional slang from Vietnamese to English

In this case, "bán muối", by implication, is understood as "to die" according to culture in most Southeast Asian Nations. Those two examples are the conception of culture - one of the specific cultural features of a country - so there is no way to transfer them directly into TL, but indirectly we use a similar word that best describes the SL meaning.

Eleventh, label translation is simply to translate labels and brand names. This activity is considered to render untranslatable words - untranslatability - of some labels and brand names. Due to the increase of technology and the economy of some countries, many foreign companies have been investing in these markets and the localization is also important for the national civilians because there are so many new languages that they do not know and those are the reasons for the existence of label translation. There are so many stores, shops, restaurants, etc on the street you will seek that have been translated in your language. For example:

\begin{tabular}{|l|l|}
\hline Best Express & Giao hàng tốt nhất \\
\hline Apple & Quả táo cắn dở \\
\hline $\begin{array}{l}\text { Single-Member Limited } \\
\text { Liability Company }\end{array}$ & $\begin{array}{l}\text { Công ty Trách nhiệm } \\
\text { Hữu hạn Một thành viên }\end{array}$ \\
\hline
\end{tabular}

\section{Table 14 Performing label translation}

Twelfth, with the term 'naturalization' in 20 ways overcoming untranslatability, a translator sometimes meets some problems about the ways people, whose English does not belong to them and not the mother tongue, pronounce a word in English by their thick brogue. For example, 'Co.opmart,' the name of a very famous supermarket with good price in Viet Nam and it 
is very reliable to many Vietnamese buyers, is pronounced "cóp-mắc" instead of /'kəu pp ma:rt/ by most of the people living in Viet $\mathrm{Nam}$; in another example, "mayonnaise," which is defined as a thick, velvety dressing comprising of egg yolks beaten with oil and vinegar and seasoned, is also pronounced in a simple way is "ma-dô-ne" instead of /meı.ə'neız/.

'Acronyms,' which is mentioned as the thirteenth strategy according to Peter Newmark, are words that formed from some important letters or letters of each of the successive parts. We can easily seek these words as a name of an organization, for instance, WHO (World Health Organization), WTO (World Trade Organization), academic titles like "Prof." stands for "professor," "Dr." for "doctor," "Mr." for a man and "Mrs." for a woman who is married, etc. In Vietnamese, there are also so many acronyms as English does, for example, Vovinam - a type of martial art with the full name is "Việt Võ Đạo," "NSUT" is the short form of "Nghệ sĩ ưu tú" - as an award for a person who devotes themselves for a specific form of art. And the final example is "NGUT" whose short form is "Nhà giáo ưu tú." This is also an award as "NSUT," but the main purpose is to fully respect some specific teachers who have been spending most of their time for their students and do the best they can to improve the educational situation in Vietnam. When translating these words, there is no other way better than keeping it as remain or express as most similarly the details as possible in order not to be lost in translation and causing mistakes that make readers more confused.

Fourteenth, 'expansion' in translation is the way a translation puts one or more than two words to fulfill the meaning of a name or a title like "Tous Les Jour" - one of the most famous bakeries in over the world started to migrate to Vietnam since 2007. People in Vietnam are now used to calling it "tiệm bánh Tous Les Jour" while there is no "bakery" word appearing in the name. Or, in another example, "trái dưa hấu" is the Vietnamese version of "watermelon" in English. The most different spot here is that "watermelon" does not contain any "fruit" itself, but in Vietnamese, we have "trái" as a composition.

To the 'contraction' in the fifteenth strategy, it is different from acronyms. 'Contraction' is simply explained as a reduced form of a word or a pair of words. For instance, "science fiction" is written in the short form as "sci-fi," "wanna" is the short form of "want to," which is used mostly in the English spoken language. In such cases, it is also considered as untranslatability because they are as well as a cultural way of speaking a language especially to some other countries whose mother tongue is not standard English like America, Singapore, etc.

The next one is about 'neologism', the sixteenth strategy, which is defined as a new word or could be the new term of a word. This happens due to the varieties in culture in every country or in the most well-known thing. First, "google" is a well-known web-based searching tool that none of us have been using since the time we knew how to use a computer and go online. By its wonderful function is that it can help you find anything in the world consisting of knowledge, newspaper, documents, games, entertainment, etc. Because of its function, many people from around the world have created a new verb, "to google," which expresses an action of using Google Search toolbar integrated into some browsers like Firefox, Google Chrome, etc., to find what we want. The next example is about an action of telling things over the truth or swaggering about anything of a braggart - "nổ." In Vietnamese, people use this term to criticize some specific persons who always show off what they have, but the others do not as in a spoken way. Second, "trolling" is also a new word, describing an action of teasing mischievously or saying something that joke or playing a nasty trick, prank to other people to make fun. For the final instance I have for this, "bóc phốt" is an action of disclosing some information which is considered to be secret for someone or an organization that might affect their personalities or damages their minds. In a lower level is just like a joke between some relationship like friends, family, relatives, etc. that not only the youths use in their daily life but also the adults in such case.

Moving to the seventh strategy, 'cultural equivalence' means to translate the culture - the ways people apply their mother language as English structures. For example, "xe mô-tô" to the Vietnamese is a kind of large motorcycle but the fact that "mô-tô" is simply a Vietnamese version of "motorcycle" in English. Or in another example, when people mention an action of twisting the gas handler of a motorcycle to warm up the engine inside, they use "đề-pa" as a verb of this. "đề-pa" is originated from "to depart." Those could not be translated because they do not share the same meaning, so they are untranslatable words again.

In the eighteenth, 'paraphrase' means expressing the given idea in another way but still keeping the same meaning as the source. In the situation below

\begin{tabular}{|c|c|}
\hline ST & TT \\
\hline $\begin{array}{l}\text { A and B are having } \\
\text { dinner in a restaurant. } \\
\text { Suddenly, B takes his } \\
\text { arm over the cup of } \\
\text { water to take food and } \\
\text { may cause the falling } \\
\text { of that cup. }\end{array}$ & $\begin{array}{l}\text { A và } B \text { đang dung bữa tối } \\
\text { tại nhà hàng. Bống nhiên, } \\
B \text { lấy tay gấp đồ ăn qua } \\
\text { khỏi chiếc ly và mém chút } \\
\text { nữa làm rơi cái ly đó } \\
\text { xuống đất }\end{array}$ \\
\hline A said: "Be careful!" & A nói: "Coi chừng đổ kìa!" \\
\hline
\end{tabular}

Table 15 Translating using paraphrasing technique from English to Vietnamese 
Even though the ST does not contain "the falling" of water, but in the TT, a translator involves in containing it.

In the nineteenth strategy with the term 'back translation.' This term of translation is quite popular in this field. The idiom "so many men, so many minds" is the same as 'back translation.' It describes as many times rendering a translation as the results won't be the same as the first time, for example.

\begin{tabular}{|l|l|}
\hline $\begin{array}{l}\text { First } \\
\text { translation }\end{array}$ & $\begin{array}{l}\text { Cô gái hôm qua tôi gặp ở bệnh viện A } \mathrm{A} \\
\text { lật vị bác sĩ }\end{array}$ \\
\hline $\begin{array}{l}\text { Second } \\
\text { translation }\end{array}$ & $\begin{array}{l}\text { A woman, whom I met yesterday at A } \\
\text { hospital, is a doctor }\end{array}$ \\
\hline $\begin{array}{l}\text { Third } \\
\text { translation }\end{array}$ & $\begin{array}{l}\text { Người phụ nữ hôm qua tôi gặp ở bệnh } \\
\text { viện làm trong ngành bác sĩ }\end{array}$ \\
\hline $\begin{array}{l}\text { Fourth } \\
\text { translation }\end{array}$ & $\begin{array}{l}\text { A woman I met yesterday at A hospital } \\
\text { is a doctor }\end{array}$ \\
\hline
\end{tabular}

Table 16 Translating using back-translation technique between English and Vietnamese

Over four translations, the meaning does not change after all. There is just only a change in the position of some words.

Finally, 'ambiguity' is one of the most difficult problems that confuse a translator with the content of a document. Here are some examples I want to make clear

\begin{tabular}{|l|l|}
$\begin{array}{l}\text { "Nghe xong tin người đó } \\
\text { mât, mẹ tôi CHÊT LẬNG" }\end{array}$ & $\begin{array}{l}\text { "John is looking } \\
\text { for a car" }\end{array}$
\end{tabular}

Table 17 Ambiguous problem in translating Vietnamese to English

In the left sentence, "chết lặng" means to be extremely sad, sorrowful and keep the posture of the body in the same as to remain with a soulless eye, but it does not mean to die. To the right sentence, "John is looking for a car" has two meanings, which cause readers ambiguous; the first one is about John is doing an action of using his eyes to search for the car; second, it means that John wants to buy himself a car, but he is in two minds about what car he should buy.

In total, those are the twenty ways to overcome the untranslatable words - so-called untranslatability - that Peter Newmark included in A textbook of translation (1988) that a translator must obtain to become more professional in dealing with the untranslatability.

\section{RESULTS AND DISCUSSION}

\subsection{Results}

In this research, I applied the qualitative method to collect wordy data instead of numeric one. Here are 15 questions in this survey, which relate to the untranslatability as well as some untranslatable words in translation from English to Vietnamese and vice versa for 20 students in the Translation and Interpretation Department.

For the problem of the most similar term to untranslatability, people consider it as a normal situation. However, some who specialize in translation major have to dig deeply into the problems not only about the vocabulary but also the structures from a language to another, especially from English to Vietnamese. According to the survey, there are four answers, which are "Literal translation, Skip translation, Contextual translation, and Literal-sense translation." Hence, the most selected option is "Skip translation." Due to they reckon that this problem is certainly absolute, so there is no need to translate them. But, under the translators' look, this is a serious problem.

To the second question - "What are the aspects of the untranslatability?", there are two aspects which can be listed as the cultural - about the culture of a country - and linguistic - about the language people use in each country.

Third, "ambiguous" and "misunderstand" are the key elements which affect the quality of translation.

Fourth, the most effective way to solve the untranslatable words is to do online searching. This is one of the most suitable solutions to deal with some documents that appear untranslatable words.

Fifth, to solve the UN, not only to obtain the specialist knowledge of translation and general, but also the deep understanding about TL culture, reading comprehension, and writing skills.

Sixth, besides applying the pen-to-paper technique in translation in solving the UN, there is another one technology. With the development of technology in today's world, most problems could be settled.

\subsection{Discussion}

This survey was created by applying the qualitative method with the purpose of finding out the property of untranslatable words, as mentioned before. Moreover, from the results achieved from this survey, it is sure not only that some words could not be translated from English to other languages, but they also cannot be rendered into Vietnamese and vice versa due to the nonequivalence in both languages. In addition, grammatical structures are also the second factor that prevents a word or a phrase from being translated into other languages.

\section{CONCLUSION}

In conclusion, untranslatability is a difficult problem that requires translators to have much knowledge about the field they do the translation; moreover, the reflection in choosing a word in TL document must be more and 
more skilful due to the rules of every language as well as different grammatical structures.

\section{REFERENCES}

[1] Catford, J. C. . A Linguistic Theory of Translation; an Essay in Applied Linguistics: By JC Catford. Oxford UP, 1965

[2] Cui, J. . On the Translation of Chinese Current Political New Words. Theory \& Practice in Language Studies, 2(5), 2012

[3] Mattar, K. . Against World Literature: On the Politics of Untranslatability. By Emily Apter. Pp. 382. London and New York: Verso, 2013. Pb.£ $19.99,2014$

[4] Ping, K. . Translatability vs. untranslatability: A sociosemiotic perspective. Babel, 45(4), 289-300, 1999

[5] Wang, J. . An Analysis of Untranslatability between English and Chinese from Intercultural Perspective. English Language Teaching, 7(4), 119-125, 2014

[6] Wang, F. . An approach to the translation of brand names. Theory \& Practice in Language Studies, 2(9), 2012

[7] E.M. Clarke, E.A. Emerson, Design and synthesis of synchronization skeletons using branching-time temporal logic, in D. Kozen (Eds.), Workshop on Logics of Programs, Lecture Notes in Computer Science, vol. 131, Springer, Berlin, Heidelberg, 1981, pp. 52-71. DOI: https://doi.org/10.1007/BFb0025774

[8] DDIMB, G., \& Ariyaratne, W. M. . Overcoming Cultural Untranslatability: With Special Reference to Wikramasinghe's 'Gamperaliya'and its English Translation, 'Uprooted'by Lakshmi de Silva and Ranga Wikramasinghe. International Journal of Research and Innovation in Social Science, 3, 303309, 2019

[9] Furness, S., \& Hollis, T. . Untranslation. London Design Festival installation, Brixton Village and Market Row, 16-24, 2017.

[10] House, R. (2001). Random House Webster's unabridged dictionary. Random House Reference.

[11] NELSON, A. . American Heritage Dictionary, 2006

[12] Thu, Đ. M., Ngọc, Đ. T. M., Vân, N. M., Ngân, L. K., Lê Thanh Hương, N. P. T., \& Lâm, Đ. B. (n.d.) TÂ̂P QUY TẮC CÚ PHÁP TIẾNG VIẸT.

[13] Stevenson, A. (Ed.). Oxford dictionary of English. Oxford University Press, USA, 2010

[14] Websters, I. I. . Dictionary. Modern, 1987
[15] Peters, P. . The Cambridge dictionary of English grammar. Cambridge University Press, 2013

[16] Jones, R. B. (1956). Nguyen-van-Khon, Anh-Vitt Tu-Dien (English-Vietnamese Dictionary (Book Review). Journal of Asian Studies, 15(4), 610.

[17] Newmark, P. . A textbook of translation (Vol. 66). New York: Prentice Hall, 1988

[18] J.P. Queille, J. Sifakis, Specification and verification of concurrent systems in CESAR, in: M. Dezani-Ciancaglini and U. Montanari (Eds.), Proceedings of the 5th International Symposium on Programming, Lecture Notes in Computer Science, vol. 137, Springer, Berlin, Heidelberg, 1982, pp. 337-351. DOI: https://doi.org/10.1007/3-540-11494-7_22

[19] C. Baier, J-P. Katoen, Principles of Model Checking, MIT Press, 2008.

[20] M. Kwiatkowska, G. Norman, D. Parker, Stochastic model checking, in: M. Bernardo, J. Hillston (Eds.), Proceedings of the Formal Methods for the Design of Computer, Communication and Software Systems: Performance Evaluation (SFM), Springer, Berlin, Heidelberg, 2007, pp. 220-270. DOI: https://doi.org/10.1007/978-3-540-72522-0_6

[21] V. Forejt, M. Kwiatkowska, G. Norman, D. Parker, Automated verification techniques for probabilistic systems, in: M. Bernardo, V. Issarny (Eds.), Proceedings of the Formal Methods for Eternal Networked Software Systems (SFM), Springer, Berlin, Heidelberg, 2011, pp. 53-113. DOI: https://doi.org/10.1007/978-3-642-214554 3

[22] G.D. Penna, B. Intrigila, I. Melatti, E. Tronci, M.V. Zilli, Bounded probabilistic model checking with the muralpha verifier, in: A.J. Hu, A.K. Martin (Eds.), Proceedings of the Formal Methods in Computer-Aided Design, Springer, Berlin, Heidelberg, 2004, pp. 214-229. DOI: https://doi.org/10.1007/978-3-540-30494-4_16

[23] E. Clarke, O. Grumberg, S. Jha, et al., Counterexample-guided abstraction refinement, in: E.A. Emerson, A.P. Sistla (Eds.), Computer-Aided Verification, Springer, Berlin, Heidelberg, 2000, pp. 154-169.

DOI: https://doi.org/10.1007/10722167_15

[24] H. Barringer, R. Kuiper, A. Pnueli, Now you may compose temporal logic specifications, in: Proceedings of the Sixteenth Annual ACM Symposium on the Theory of Computing (STOC), ACM, 1984, pp. 51-63. DOI: https://doi.org/10.1145/800057.808665

[25] A. Pnueli, In transition from global to modular temporal reasoning about programs, in: K.R. Apt 
(Ed.), Logics and Models of Concurrent Systems, Springer, Berlin, Heidelberg, 1984, pp. 123-144. DOI: https://doi.org/10.1007/978-3-642-82453$\underline{15}$

[26] B. Meyer, Applying "Design by Contract", Computer 25(10) (1992) 40-51. DOI: https://doi.org/10.1109/2.161279

[27] S. Bensalem, M. Bogza, A. Legay, T.H. Nguyen, J. Sifakis, R. Yan, Incremental component-based construction and verification using invariants, in: Proceedings of the Conference on Formal Methods in Computer-Aided Design (FMCAD), IEEE Press, Piscataway, NJ, 2010, pp. 257-256.

[28] H. Barringer, C.S. Pasareanu, D. Giannakopolou, Proof rules for automated compositional verification through learning, in Proc. of the 2nd International Workshop on Specification and Verification of Component-Based Systems, 2003.

[29] M.G. Bobaru, C.S. Pasareanu, D. Giannakopoulou, Automated assume-guarantee reasoning by abstraction refinement, in: A. Gupta, S. Malik (Eds.), Proceedings of the Computer Aided Verification, Springer, Berlin, Heidelberg, 2008, pp. 135-148. DOI: https://doi.org/10.1007/978-3540-70545-1_14 